\title{
Strategi Pemberdayaan Desa Adat dengan Pembentukan Forum Komunikasi antar Desa Adat
}

Ni Gusti Ayu Kartika ${ }^{1}$

1Jurusan Ilmu Komunikasi dan Penerangan Agama Fakultas Dharma

Duta, Institut Hindu Dharma Negeri Denpasar

\begin{abstract}
Traditional village is a traditional institution that serves as a forum for the villagers to perform various spiritual, cultural, social and economic, in order to achieve tranquility and prosperity of life born inner. The indigenous village autonomy manifests itself in the administration of the government, which can apply in and out, and shoulder to shoulder with the village office in carrying out the development. In this era of globalization, indigenous villages experience internal and external challenges that may interfere with their sustainability. With the establishment of communication forums between custom villages, it is expected that traditional villages will exist, resilient and empowered in facing these challenges.

Keywords Desa Adat, Communication Forum, Balinese Tradition
\end{abstract}

\section{PENDAHULUAN}

Desa adat merupakan suatu lembaga tradisional yang bersifat otonom yang dilandasi oleh nilai-nilai asli bangsa Indonesia dan bercorak sosial religius. Desa adat mempunyai kekuasaan untuk menetapkan ketentuan-ketentuan hukum sendiri yang dikenal dengan istilah awig-awig desa oleh karena itu di dalam desa adat dijumpai, adanya berbagai aturan-aturan yang dibentuk dan ditaati bersama oleh masyarakat desa.

Struktur organisasi desa adat bervariasi sesuai dengan besar-kecilnya desa adat. Pada desa adat yang kecil, struktur organisasinya bersifat sederhana, dan aturan-aturan yang dibentuknya mengatur hubunganhubungan hukum yang sederhana pula. Pada desa adat yang luas, dapat dibagi menjadi beberapa sub desa yang disebut dengan istilah banjar. Apabila banjar itu sudah besar, dapat pula dibagi menjadi sub-sub banjar yang disebut tempek. Dengan demikian pada desa yang besar diperlukan adanya aturan-aturan yang bersifat kompleks pula, agar dapat mewujudkan ketertiban dan ketentraman masyarakat.

Desa adat berkembang sesuai dengan dinamika kehidupan masyarakat. Bertambahnya jumlah penduduk dan meningkatnya kebutuhan hidup

\footnotetext{
${ }^{1}$ gusti_kartika@ihdn.ac.id
} 
masyarakat berpengaruh terhadap desa adat. Selain itu, modernisasi yang dialami oleh masyarakat sesuai dengan pesatnya kemajuan jaman, merupakan tantangan bagi desa adat. Tantangan-tantangan yang dihadapi desa adat dapat berupa terbatasnya areal desa adat, sehingga pembangunan fisik yang dibangun oleh masyarakat dan program pemerintah sering menggangu kelestarian pola menetap desa adat. Rendahnya sumber daya manusia tidak mampu menghadapi besarnya tantangan-tantangan yang terjadi dalam masyarakat, seperti terjadinya kasus-kasus yang tidak dapat diselesaikan oleh desa adat, sehingga menimbulkan konflik-konflik yang berkepanjangan.

Dengan adanya tantangantantangan yang dihadapi oleh desa adat, baik tantangan yang bersifat internal, yang datang dari kesadaran masyarakat sendiri untuk meningkatkan diri, maupun tantangan eksternal yang datang dari dunia luar, yang berkembang seirama dengan perkembangan masyarakat modern, perlu adanya upaya-upaya untuk mengatasinya. Upaya desa adat dalam mengatasi tantangan itu merupakan tolak ukur untuk mengetahui, sejauh mana desa adat memiliki ketahanan dan keberdayaan, sehingga tetap eksis di tenagh kehidupan masyarakat yang semakin kompleks. Salah satu strategi desa adat dalam menghadapi tantangan-tantangan tersebut antara lain dengan pembentukan forum komunikasi antar desa adat. Dengan kata lain, melalui wadah forum komunikasi antar desa adat itu, segala permasalahan, tantangan dan hambatan yang dihadapi desa adat diharapkan dapat diatasi.

\section{PEMBAHASAN}

\section{Perkembangan Desa Di Bali}

Seperti juga di Jawa, atau daerah lainnya di Indonesia, juga di Bali dikenal adanya desa dan aturan-aturannya yang mengikat penduduk di lingkungannya. Sebelum sampai kepala pembicaraan mengenai desa adat, baik dibicarakan dahulu desa Bali dari masa-masa sebelumnya. Munculnya desa di Bali kalau mau mencarinya ke belakang ke masa lampau kita mungkin menemukan asalnya paling tidak sejak zaman Bali kuna yakni sebelum kedatangan raja-raja turunan Majapahit. Pada masa itu sekurang-kurangnya antara abad ke-9 sampai dan abad ke-14 masyarakat Bali telah mengenal masyarakat desa yang disebut krama. Untuk menunjuk desa digunakan istilah wanua atau banua seperti tercatat dalam prasasti desa Trunyan abad ke-10. Dapat diduga bahwa wujud desa pada masa ini lebih merupakan kelompok cikal bakal atau keturunan pendiri pemukiman yang sejak awal telah mendiami daerah tertentu. Meskipun ada yang disebut raja, namun kekuasaannya tidak masuk mencampuri keadaan di desa. Pada masa ini dapat disebut bahwa desa-desa itu lebih mandiri dengan sistem dan kepalanya sendiri. Secara tradisi sering diungkapkan bahwa masa ini muncul pengaruh Empu Kuturan dari Jawa Timur, namun dapat dimengarti pengaruhnya lebih berkisar pada sistem organisasi desa, dan kepercayaan Hindu Jawa pada zaman Majapahit abad ke-14, desa-desa tampak semakin menerima pengaruhnya, dan menumbuhkan bentuk desa dibawah pengawasan rajaraja. Tampak desa-desa mulai mendapat pengawasan dari kekuasaan supra desa atau kerajaan. Paling tidak pengawasan atas desa-desa di Bali muali sejak abad 
ke-16 setelah raja Bali atau turunan Majapahit lebih mantap berkedudukan di Gelgel (Lekkerkerker, 1926: 330). Keadaan ini membuat desa-desa semakin menunjukkan fungsinya yang ganda, fungsi desa sebagai kelompok cikal-bakal, atau penghuni yang lekat dengan perilaku kepercayaan pada leluhur, atau religius, dan fungsi desa sebagai kelompok sosial politik yang dibina oleh kekuatan luar (raja). Dengan pecahnya pengaruhnya kuat Gelgel di abad ke-17 karena adanya pemberontakan I Gusti Agung Maruti (1651) muncul kerajaan-kerajaan di Bali. Raffles dalam discoursenya (tahun 1815) menyebutkan antara lain : pulau Bali dibagi menjadi 7 buah kerajaan yang masing-masing merdeka satu sama lain, Klungkung adalah sebagai kerajaan tertingi atau terhormat, dan raja-rajanya berasal dari turunan Majapahit. Disini raja dibantu oleh seorang petugas yang disebut perbakal yang sekarang disebut perbekel. Keterangan ini mengandung makna bahwa sebuah desa telah terbuka karena adanya hubungan dengan kekuasaan raja. Dengan adanya perbekel sebagai wakil dari raja yang ditugaskan mengawasi keadaan desa, dapat dikatakan bahwa desa telah menerima kehadiran faktor luar, yangmau tidak mau dapat menjadi agen bagi adanya perubahan di dalam masyarakat desa. Semakin meresapnya kkeuasaan Majapahit, mendorong pendatang baru ini menjadi luluh dengan penduduk Bali, membawa kekuatan desa-desa semakin menyatu dengan ketentuan raja-raja. membuat hubungan raja-pengiring, semacam hubungan patron-client atau model hubungan jumbuhing Kawulu Gusti seperti di Jawa semakin nampak. Hubungan semacam ini tampak membuat ikatan antara adat atau tradisi
Bali dan agama Hindu yang dibawa oleh para raja dari Jawa semakin melekat, sulit dipisahkan. Apabila terdapat pertentangan di desa, tidak lagi hanya tetua, atau prejuru desa yang berusaha mendamaikannya, tetapi bila perlu kekuatan supra desa yang diwakili perbekel atau punggawa dapat ikut memecahkan. Awig-awig desa yang disusun juga dapat disampaikan kepada perbekel. Liefrinck (1927) menyebut bahwa perbekel/punggawa adalah merupakan wakil raja di daerah itu. Hal itu memberi petunjuk bawah desa-desa Bali meskipun tetap berada dibawah pemimpin (tetua atau bendesanya) sendiri, telah mendapat pengaruh, dan mungkin perubahan akibat hubungannya dengan kekuatan luar. Akan tetapi tampak bahwa perubahan yang terjadi masa itu tidak menggangu sistem kepemimpinan desa berdasarkan musyawarah para anggotanya.

Pada desa-desa yang lebih tua, tidak terdapat petunjuk bahwa raja-raja mengubah wilayah (payar) desa yang sebelumnya telah menjadi bagian, atau hak desa untuk mengaturnya. Disini penguasa desa biasanya diambil dari orang-orang yang dipandang sebagai kelompok pemula, atau pendiri desa. Karena itu sistem pemujaan mereka lebih terpusat kepada pemujaan kepada roh leluhur, selain Yang Maha Kuasa (c) yang tampak dari bentuk-bentuk bangunan pemujaan yang ada di desa. Desa-desa seperti ini umumnya terletak di daerah pegunungan (di Bali Utara, dan Bali Timur). Sebagai contoh : desa Cempaga, Kedisan (di Buleleng), desa Trunyan (di Bangli), desa Tenganan (di Karangasem). Sistem kepemimpinan umumnya diambil dari orang tua-tua berdasarkan musyawarah anggota, atau 
urutan dalam perkawinan yang ditetapkan dalam awig-awig desa.

Suatu masa, ketika awig-awig desa dikatakan lenyap karena tempat menyimpannya (Bale Agung) terbakar, maka para pemuka desa memohon kepada raja (Raja Karangasem dan Klungkung) agar awig-awignya dapat diganti. Atas izin/petunjuk raja, dikirim dua orang juru tulis untuk menuliskan kembali awig-awig desa itu. Penulisnya dibuat berdasarkan keterangan dari orang-orang tua yang masih ingat tentang awig-awignya terdahulu. Demikian penulisan awig-awig di desa Tenganan dilakukan tahun 1842. Kemudian (1925) masih dilakukan penyempurnaan oleh desa. Dari awigawig yang ditulis kembali itu tampak bahwa satu perubahan muncul, yakni mulai diperbolehkan mengambil istri dari orang luar desa, asal masih muda (belum pernah kawin) dan dibakar saat upacara kematiannya (megama manunjel).

Keadaan itu juga menunjukkan bahwa dengan kedatangan pengaruh Majapahit, tampak desa-desa Bali mulai semakin diawasi dengan menempatkan tokoh-tokoh yang ditentukan raja. Disebutkan, para pasek, bendesa disebarkan ke desa-desa di Bali untuk mewakili raja di desa. Paling pentingrupanya bagaimana penduduk desa dapat diawasi untuk tidak melakukan gejolak dalam hubungannya dengan kekuasaan raja diatasnya, dan karenanya proses adaptasi dari kekuasaan atas dalam sistem pemerintahan desa telah terjadi, membuat kehadiran pengawasan raja di desa tidak membawa gejolak di dalam masyarakat. Sifat pemerintahan desa yang lebih demokratis terus dilaksanakan dengan tetap memperhatikan unsur-unsur dari tokohtokoh pemula desa. Dalam hubungan ini suatu negosiasi dapat saja terjadi antara tokoh desa dan wakil pihak kerajaan.

Dalam kedudukan itu desa di Bali (dalam arti lembaga tradisional) tetap menampilkan diri sebagai wadah kelompok masyarakat yang semakin kompleks dalam peranannya, menangani masalah-masalah baik yang berhubungan dengan agama, kepercayaannya kepada leluhur, maupun masalah sosial ekonomi penduduk, dan secara politik terkait dengan kekuasaan raja di atasnya. Semua itu tampak menyatu dalam rasa dan anggapan para pendukungnya (penduduk desa). Itulah yang melahirkan tradisi, kebiasaan yang sering berbeda antara satu tempat dengan tempat (desa yang lain). Dengan demikian disini juga terjadi dua model ikatan tradisi dalam masyarakat desa yaitu : ikatan desa dan ikatan kerajaan/feodal (meminjam konsep yang diajkan oleh D.H.Burger).

\section{Karakteristik Desa Adat}

Desa adat adalah suatu organisasi yang tumbuh dan berkembang secara wajar dalam masyarakat menurut kodratnya. Kriteria desa adat ditandai oleh adanya kesatuan territorial yang berupa wilayah tempat tinggal warga desa, hanya krama (warga) desa beserta pengurusnya yang berupa pendukung desa adat, dan adanya Kahyangan Desa baik dalam bentuk Kahyangan Tiga yaitu Pura Puseh, Pura Bale Agung dan Pura Dalem maupun dalam bentuk Kahyangan desa lainnya sebagai simbul tempat pemujaan bersama kepada Sang Hyang Widhi Wasa (Tuhan Yang Maha Esa).

Desa adat mempunyai pengurus yang dapat bertindak ke dalam dan ke luar mewakili desanya, mempunyai kekayaan materiil dan immaterial. Kegiatan desa adat meliputi berbagai bidang, seperti 
bidang keagamaan, kesenian, sosial dan ekonomi. Penampilan warga desa dalam berbagai kegiatan yang dilakukan secara kolektif menunjukkan bahwa desa adat mempunyai ciri-ciri yang bersifat sosial, religious dan komunal.

Pengurus desa adat atau prajuru desa adat lazimnya disebut dengan istilah kelian, kelian adat, kelian desa dan bendesa. Susunan kepengurusan desa adat bervariasi, namun secara umum terdapat unsur-unsur yang berfungsi sebagai kelian/bendesa (ketua), penyarikan (sekretaris, dan patengen atau juru raksa (bendahara), serta dibantu oleh kesinoman.

Desa adat sebagai lembaga yang tumbuh dan berkembang dari masyarakat mempunyai potensi yang bersifat tradisional dan spesifik. Potensi desa adat itu dapat dipelihara, dikembangkan dan dijadikan modal untuk menunjang pembangunan pada berbagai aspek kehidupan. Potensi desa adat yang memegang peranan penting bagi kehidupan masyarakat adalah sebagai berikut :

a. Aspek Religius

Desa adat merupakan wadah tempat hidup dan sumber pelaksanaan agama Hindu yang diwujudkan dalam pelaksanaan upacara agama. Pelaksanaan upacara agama berkaitan erat dengan tempat-tempat pemujaan yang tersebar pada setiap desa adat. Pada setiap desa adat ada berbagai jenis pura dan setiap pura mempunyai pengempon, pengemong dan penyungsung. Pengempon pura berfungsi untuk memelihara, merawat, maupun membersihkan pura sehari-hari. Pengemong pura berfungsi untuk mengurus dan melakukan berbagai kegiatan, seperti pembangunan, dan pelaksanaan upacara. Penyungsung pura adalah warga masyarakat yang berkewajiban melakukan pemujaan di pura tersebut.

Pada desa adat, fungsi pengurus pura kadang-kadang dilaksanakan oleh prajuru desa adat, yaitu kelihan adat, yang berkewajiban melaksanakan berbagai kegiatan, seperti pembangunan dan melaksanakan berbagai kegiatan, speerti pembangunan dan pelaksanaan upacara dengan melibatkan pengempon dan para penyungsung. Kewajiban setiap warga dapat berupa membayar iuran uang, bahan bangunan dan tenaga. Sebagian besar pelaksanaan pembangunan dilakukan secara bersama atau gotong royong.

Kekayaan materiil pura dapat berwujud tanah yang disebut laba pura. Laba pura yang luas dan mempunyai penghasilan banyak berpengaruh terhadap pembangunan pura serta pelaksanaan berbagai kegiatan upacara. Sebaliknya, pur ayang tidak mempunyai tanah laba, pembangunan dan kegiatan upacara dilakukan dengan memungut iuran yang disebut peturunan dari para penyungsung pura.

Warga desa adat selain terikat pada Kahyangan Tiga, mereka juga terikat pada berbagai tempat pemujaan keluarga, seperti pura dadya, dan sanggah/merajan masing-masing. Ikatan warga masyarakat terhadap pemujaan keluarga itu menunjukkan bahwa mereka ada hubungan yang bersifat genealogis. Oleh karena itu, setiap warga desa adat selain bersatu karena ikatan territorial, yiatu bersatu karena bertempat tinggal pada satu desa adat yang diikat oleh Kahyangan Desa, juga bersatu ikatan geneologis, yakni terikat oleh pura dadya masing-masing.

b. Aspek Sosial Budaya 
Masyarakat desa mempunyai berbagai kegiatan sosial, seperti dalam melaksanakan upacara panca yadnya, pembangunan berbagai bangunan fisik, serta berbagai kegiatan sosial lain, yang dilakukan secara kekeluargaan atau gotong royong. Sistem kerja gotong royong itu menunjukkan bahwa desa adat mempunyai karakteristik komunalistik.

Hasil karya masyarakat desa terwujud dalam bentuk berbagai karya seni, seperti tampak pada berbagai bangunan yang dilengkapi oleh adanya berbagai seni lukis dan seni ukir. Dalam pelaksanaan kegiatan upacara, ditampilkan berbagai seni tari, seni tabuh, seni suara dan sebagainya. Hal itu menunjukkan bahwa masyarakat desa telah melaksanakan berbagai kegiatan yang bersifat budaya. Kegiatan aspek sosial budaya masyarakat desa adat itu mempunyai daya tarik bagi wisatawan.

c. Aspek Politik

Desa adat sebagai lembaga tradisional mempunyai otonomi asli. Sejak berdirinya desa adat itu, prajuru desa adat mengatur rumah tangganya sendiri, dan dapat bertindak mewakili desanya melakukan interaksi dengan desa asli. Prajurus desa adat menyelesaikan sengketa-sengketa yang terjadi dalam masyarakat berpedoman kepada awigawig desa yang dibuat desa adat yang bersangkutan dan dapat menjatuhkan sanksi adat kepada warga desa atau warga lain yang melanggar awig-awig desa adat.

Otonomi desa adat adalah berdasarkan hukum adat atau hukum asli bangsa Indonesia, pada hakekatnya tumbuh di dalam masyarakat. Isi otonomi desa adat itu sangat luas, yang meliputi berbagai aspek kehidupan manusia, namun tetap berada di bawah pemerintahan pusat.
Sifat otonomi desa adat itu fleksibel, elastic, kenyal, dan nyata.

d. Aspek Ekonomi

Desa adat mempunyai lembaga perekonomian adat, seperti pasar desa, lumbung desa dan sebagainya, yang digunakan oleh masyarakjat desa untuk memnuhi kebutuhan hidupnya. Dewasa ini pada setiap desa adat dibentuk Lembaga Perkreditan Desa (LPD) yang berfungsi untuk meningkatkan taraf kehidupan masyarakat desa telah berhasil menghimpun dana yang cukup banyak, sehingga membantu kelancaran pelaksanaan desa adat.

Fungsi dan peranan desa adat sesuai dengan pelaksanaan kegiatan dalam berbagai aspek kehidupan, terintegrasi dalam awig-awig, awig-awig desa adat pada dasarnya mengatur hubungna manusia dengan Tuhan yang diwujudkan dalam berbagai kegiatan persembahyangan di pura, mengatur hubungan manusia dengan sesamanya yang diwujudkan dalam berbagai kegiatan sosial, dan mengatur hubungan manusia dengan alam lingkungannya, yang diwujudkan dengan berbagai kegiatan dalam mengolah alam untuk mendapat sumber kehidupan guna memnuhi kebutuhan materiil dan spiritual. Ketegasan dan keluwesan prajuru desa melaksanakan awig-awig dan ketaatan masyarakat terhadap awigawig mencerminkan tercapainya ketertiban dan ketentraman masyarakat. Kekuatan awig-awig desa adat menyatukan warganya dan melindungi setiap warga desa dalam berupaya memnuhi kebutuhan berbagai aspek kehidupan menunjukkan bahwa desa dapat menjaga kelangsungan hidupnya. Terbentuknya awig-awig desa ada dalam masyarakat sendiri dilandasi oleh nilainilai asli bangsa kita. Aturan-aturan, 
ketentuan-ketentuan, atau hukum itu, merupakan hukum adat. Dengan demikian, awig-awig desa adat Bali merupakan hukum adat. Dengan demikian, awig-awig desa adat di Bali merupakan hukum adat yang mengandung nilai-nilai yang telah ada secara turun-temurun di dalam masyarakat, dan mengandung unsur agama Hindu yang dianut oleh warganya.

\section{Desa Adat dalam Sistem Pemerintahan Negara}

Dengan berdirinya Negara Kesatuan Republik Indonesia maka wilayah Indonesia merupakan satu kekuasaan yang berada di tangan negara. Hal itu berarti Negara mempunyai kekuasaan untuk mengatur keberadaan desa adat di Bali yang disesuaikan dengan berbagai kepentingan Negara. Berdasarkan pasal 18 UUD 1945 ditetapkan bahwa pembagian daerah Indonesia atas daerah besar dan kecil, dengan bentuk susunan pemerintahannya ditetapkan dengan Undang-Undang dengan memandang dan mengingati dasar permusyawaratan dalam system Pemerintahan nengara dan hak-hak asalusul dalam daerah-daerah yang bersifat istimewa. Dengan memperhatikan ketentuan tersebut, jelaslah bahwa desa adat di Bali tergolong sebagia daerah yang mempunyai susunan asli dipandang pula sebagai daerah yang bersifat istimewa, sehingga dalam pembuatan hukum oleh Negara, kedudukan serta asal-usul dari daerah-daerah itu tetap akan diperhatikan.

Ditinjau dari UU No. 5 Tahun 1979 tentang Pemerintahan desa, dan pasal 1 ditetapkan bahwa : Desa adalah suatu wilayah yang ditempati oleh sejumlah penduduk sebagai kesatuan masyarakat termasuk di dalamnya kesatuan masyarakat hukum yang mempunyai organisasi pemerintahan terendah langsung di bawah camat dan berhak menyelenggarakan rumah tangganya sendiri dalam ikatan Negara Kesatuan Republik Indonesia. Berdasarkan ketentuan-ketentuan tersebut di atas, secara umum desa adat di Bali diakui keberadaannya. Selanjutnya, di dalam penjelasan nomor 6 Undang-Undang No. 5 Tahun 1979 menegaskan bahwa undang-undang ini tetap mengakui adanya kesatuan masyarakat termasuk di dalam kesatuan masyarakat hukum, adat-istiadat dan kebiasaan-kebiasaan yang masih hidup sepanjang menunjang kelangsungan pembangunan dan Ketahanan Nasional.

Pemerintah Daerah Tingkat I Propinsi Bali berdasarkan Perda No. 6 Tahun 1986 pada pokoknya menegaskan bahwa desa adat pada hakekatnya merupakan kesatuan masyarakat hukum adat yang mempunyai satu-kesatuan tradisi dan tata krama pergaulan hidup masyarakat secara turun-temurun dalam ikatan Kahyangan Tiga (Kahyangan Desa) yang mempunyai wilayah tertentu dan harta kekayaan senidri serta berhak mengurus rumah tangganya sendiri. Dengan demikian, berdasarkan peraturan perundang-undangan Negara, baik dari Pemerintah Pusat maupun Pemerintah Daerah Bali memandang bahwa desa adat di Bali mempunyai kedudukan yang cukup berarti sebagai nilai-nilai luhur warisan budaya bangsa yang perlu dijaga kelestariannya, dan diakui peranannya dalam pembangunan guna mewujudkan ketentraman dan kesejahteraan masyarakat.

Keberadaan desa adat dalam sistem pemerintahan Negara seperti termasuk pada peraturan perundang-undangan di atas masih menimbulkan permasalahan, 
mengingat di Bali selain ada desa adat yang tumbuh berkembang dari masyarakat, ada pula desa dinas. Perbedaan desa dalam pengertian desa adat dan desa dalam pengertian administrasi sudah ada sejak pemerintahan Hindia Belanda (Huger, 1932), Desa yang merupakan masyarakat hukum adat dan hukum agama di Bali telah ada semenjak jaman dahulu, sejak tahun 1908 ketika penjajahan Belanda tiba di Bali, dibentuklah satuan-satuan ketatanegaraan baru yang disebut desa dinas, sementara desa lama disebut desa adat. Urusan agama dan adat dipegang oleh desa adat, sedangkan urusan administrasi pemerintah dilakukan oleh desa dinas (Talizidulu Ndraha, 1984). Besar kecilnya desa adat dan desa dinas bervariasi, antara lain, ada desa adat yang sama dengan desa dinas, ada beberapa desa adat yang berada di bawah satu desa dinas, tetapi ada pula desa adat yang terdiri dari beberapa desa dinas. Pada umumnya pola yang paling banyak, adalah beberapa desa adat berada di bawah satu desa dinas, tetapi ada pula desa adat yang terdiri dari beberapa desa dinas. Pada umumnya pola yang paling banyak, adalah beberapa desa adat berada di bawah satu desa dinas.

Desa dinas yang berkaitan dengan urusan kedinasan/administrasi langsung berada di bawah camat, sedangkan desa adat yang mengurus kepentingan adat dan agama tidak berkaitan secara langsung dengan camat. Dengan adanya dua jenis desa itu, menunjukkan sistem pemerintahan desa, yiatu pemerintahan desaa adat dan pemerintahan desa dinas, yang kadang-kadang desa dinas menunjukkan dominasinya, sehingga menyebabkan pemerintahan desa adat melemah.
Hubungan kerja antara Prajuru desa adat dengan Kepala desa adalah bersifat konsultif dan koordinatif. Dalam pelaksanaan pembangunan kedua desa itu dapat bekerja bahu membahu sehingga program pembangunan itu berjalan lancar. Namun kadang-kadang kepala desa bersifat dominan, sehingga bendesa adat tampak tidak berdaya, dengan demikian kepala desa dapat mengambil kebijakan-kebijakan tidak sesuai dengan kebutuhan masyarakat.

Menurut Shastri (1963: 7-13) Pulau Bali telah dikunjungi pelaut India sejak tahun 300 sebelum Masehi. Mahamenteri Kerajaan Maurya memberitakan di dalam bukunya "Artha Sastra", bahwa pelaut India telah mengunjungi negerinegeri yang terletak di sebelah timur laut Benggala, yaitu Swarna Dwipa, Kudika Dwipa, dan lain-lainnya. Shastri juga mengintepretasikan, bahwa Pulau Bali juga telah disebut-sebut di dalam Kitab Ramayana yang monumental itu dalam episode penjelasan sugriwa menerangkan kepada Winata. Pulau Bali sebagai tempat tinggal sebuah komunitas suku bangsa telah dikenal berabad-abad yang lampau.

Eksistensi suku Bangsa Bali yang mendiami pulau kecil yang disebut pulau Bali, selama ini dikenal sebagai pemeluk agama Hindu yang secara kuantitatif sedikit saja jika dibandingkan dengan jumlah penduduk beragama lain di Indonesia. Adrian Vickers pada awal artikelnya yang berjudul "Hinduism and Islam in Indonesia: Bali and the Pasisir World" (1987: 31) mengandaikan Bali sebagai sebuah "Pulau Hindu" di tengah "Lautan Muslim" untuk menggambarkan keminoritasan masyarakat Hindu (Bali) di Indonesia. Meskipun masyarakat Bali (Hindu) tergolong masyarakat minoritas di Indonesia, namun masih mampu 
memegang teguh agama dan kebudayaan Hindu yang diwarisinya. Bahkan Goris (1974: 17-19) dalam testimoninya menyatakan bahwa masyarakat Bali merupakan masyarakat religius yang intens mengimplementasikan ajaran agama yang diyakini. Antara kehidupan beragama dengan kehidupan sosial seringkali berhimpitan, bahkan antara kehidupan sosial dan keagamaan dapat dikatakan identik. Artinya, aktivitas sosial sehari-hari senantiasa berhubungan dengan agama yang dianut oleh mereka. Kenyataan ini barangkali yang menyebabkan. Hildred Geertz (1985: 1823 dalam Vickers, 1987: 31) menggambarkan situasi kehidupan sosial di Bali dengan menyatakan, "What is philosophy in Java is theacter in Bali". Bahkan jauh sebelum itu, entah sengaja atau kebetulan saja, Ferñao Mendez Pinto, seorang pelaut Portugis menyebut pulau Bali sebagai Java Minor (Agung, 1989: 1).

Berbagai sebutan kepada sebuah pulau kecil yang bernama pulau Bali ini telah dituliskan oleh orang-orang yang mengunjunginya. Seorang penulis asing bernama Hickman Powel, pada tahun 1930 memberi sebuta The Paradise Island kepada sebuah pulau yang memiliki luas wilayah hanya 5.632,86 km2 atau 563.286,40 Ha ini. Sementara itu, Nehru menyebut pulau itu sebagai penulis tadi tiada lain adalah pualu Bali, pulau Dewata tempat bersemayamnya Dewa-Dewi dari kahyangan, tempat Maharesi memantapkan tapa-bratayoga-samadi dan mencapai kelepasan.

Apa yang membuat mereka memutuskan untuk memberi nama kepada pulau kecil itu dengan sebutan pulau sorga? terdapat beberapa alasan inti, yaitu : pertama, mayoritas penduduknya menganut Hindu Dharma yang tercermin dalam berbagai aspek kehidupan masyarakat, mulai mereka bangun pagi, melaksanakan kegiatan keseharian, sampai pada ketika mereka melakukan kreativitas kesenian, seluruhnya mencerminkan nilai-nilai Hindu : kedua, tata kemasyarakatan diatur dengan tertib berdasarkan prinsip harmoni Tri Hita Karana, sehingga masyarakat senantiasa dituntut untuk tetap menjaga keselarasan dan keseimbangan hubungan antara dirinya dengan Tuhan-sang maha pencipta, antara manusia dengan sesamanya, dan antara manusia dengan lingkungan alam; ketiga, masyarakat Bali memiliki aneka ragam kesenian persembahan dan tontonan yang sarat dengan nilai filsafat kehidupan, terutama berhubungan dengan konsepsi dualisme yang dibuat hitam-putih, bahwa perilaku yang dilandasi oleh kecurangan, kejahatan, ketidakjujuran, keserakahan pada akhirnya akan mengalami kekalahan dan kehancuran. Keempat ditemukan beriburibu pura dalam berbagai bentuk, kedudukan, dan fungsinya sebagaimana tampak pada tabel berikut.

Keempat fenomena itu lahir dari tatanan nilai Hindu Dharma, terutama pada dorongan konsepsi bakti marga dan karma marga. Masyarakat Bali disosialisasi dan dibesarkan oleh tuntutan hati nurani untuk mempersembahkan yang terbaik dari yang mereka miliki. Mereka terbiasa bekerja tanpa motivasi terhadap hasil yang berlebihan. Dengan landasan moral Hindu Dharma, mereka berusaha bekerja sebaik-baiknya sebagai bentuk persembahan. Karena itu, bagi sebagian besar masyarakat Bali kerja adalah yadnya. 
Kehidupan sosial-religius masyarakat Bali yang demikian itu, melahirkan berbagai bentuk lembaga sosial kemasyarakatan yang kuat karena dilandasi oleh semangat gotong royong. Lembagalembaga sosial itu tumbuh subur karena adanya ikatan yang kuat karena homogenitas kepercayaan sehingga terjadi penguatan solidaritas dalam lembaga-lembaga sosial kemasyarakatan yang terwujud (Sartono, 1990: 106-109). Lembaga-lembaga sosial yang terwujud melalui proses sejarah, sosial masyarakat Bali yaitu, pura, griya, puri/jero, desa adat, banjar, subak, dan sekaha. Lembaga-lembaga sosial kemasyarakatan tersebut berkaitan dengan sistem religiusitas kemasyarakatan masyarakat Bali.

Pada masa yang lalu, sebuah kerajaan di Bali membawahi beberapa desa yang disebut Desa Adat. Masing-masing Desa Adat tersebut dipimpin oleh seorang Kepala Desa yang disebut punggawa yang dipilih oleh warga secara langsung. Sekarang, Kepala Desa Adat disebut Kepala Desa (kades). Desa adat, terdiri dari beberapa banjar (kelompok) yang disatukan dalam satu kesatuan wilayah adat. Penyatuan tersebut ditandai dengan dimilikinya tiga buah pura yang disebut Kahyangan Tiga, yaitu pura desa, pura puseh, dan pura dalem. Disamping itu, sebuah desa adat memiliki sebuah kuburan sendiri.

Sejak diterbitkannya perda No. 6 tahun 2003, nama desa adat sebagai satu kesatuan wilayah pemerintahan diganti dengan nama Desa Pakraman. Biasanya Desa Pakraman memiliki awig-awig (semacam anggaran dasar/anggaran rumah tangga) yang mengatur hak dan kewajiban anggota Desa Pakraman (krama desa) serta berbagai sangsi yang akan ditimpa apabila anggota melanggar aturan yang termuat di dalam awig-awig. Sangsi yang ditimpakan kepada anggota yang melanggar aturan awig-awig desa itu bisa sangat ringan berupa sejumlah uang dan bentuk lainnya. Sangsi yang paling berat yang dikenakan kepada krama desa apabila melanggar peraturan yang telah ditetapkan adalah kasepekang (disisihkan). Kasepekang ini juga ada tingkatannya, bisa berupa larangan berbicara dengan yang dikenai hukuman dalam kurun waktu tertentu, bisa pula dikeluarkan dari desa.

Di dalam Desa Pakraman, sekarang ini ada juga desa dinas yang dipimpin oleh seorang Lurah yang bertugas melayani berbagai keperluan warga. Lurag tidak dipilih langsung oleh warga, namun merupakan aparat desa yang ditempatkan oleh bupati atau walikota yang membawahinya. Namun, tidak semua Desa Pakraman memliki Lurah sehingga sampai sekarang masih banyak Desa Pakraman menyelenggarakan pemilihan langsung untuk memilih kepala desa.

Pada mulanya sebuah Desa Pakraman dibangun berdasarkan konsep Tri Hita Karana. Sebagai konsepsi kebudayaan, Tri Hita Karana terimplementasi ke dalam tiga dimensi. Pertama, hubungan manusia dengan Tuhan (Sukerta Tata Agama). Dalam konsepsi ini ditekankan penting adanya Kahyangan Tiga bagi warga setiap desa adat. Terpeliharanya pelinggih dan ritus berbagai bentuk pendalaman agama di wilayah suatu desa adat merupakan isi inti konsepsi sukerta tata agama, sebagai dimensi yang berhubungan dengan supernatural, maka ditanamkan pembenaran terhadap hal yang Supreme, baik melalui keyakinan religi, ritus, mitologi, dan kontraksi sosial. Pendek kata, dalam dimensi ini ditekankan bahwa manusia 
adalah insan yang malang (follen creatures) yang kelangsungan hidupnya hanya hanya mungkin berada dalam dunia sosial yang tertib. Masyarakat cendrung dapat dikatakan sebagai produk aturan keagamaan, ketimbang sebagai insan yang mampu membentuk dan merencanakan dunia sosial mereka sendiri.

Terbentuk hal ini karena proses pelembagaan makna, nilai, dan simbol Parahyangan bersifat sosial utama (par excellence). Setidaknya ini dapat dipahami dari adanya pengakuan (1) terhadap kekuasaan dan kekuatan di belakang yang disimbolkan; (2) yang suci selalu ditandai dengan kekaburan (ambiguity) setidaknya hal ini ditunjukkan dengan adanya klasifikasi simbolik berupa binary opposition; (3) yang suci tersebut harus dilihat sebagai nonutilitaian, nonempiris dan tidak melibatkan pengetahuan; (4) kualitas yang sucui tidak intrinsic pada objek, tetapi diberikan pada objek tersebut oleh pikiran dan perasaan keagamaan; (5) yang suci selalu memberikan dukungan serta kekuatan bagi para penganutnya; dan (6) ia menyampaikan kewajiban-kewajiban moral dan etika yang menjadi keharusan penganutnya.

Kedua, hubungan manusia dengan manusia (pawongan) dalam terminologi lain juga disebut Sukerta Tata Pawongan. Dalam dimensi ini ditekankan adanya etika dalam bertingakh laku, baik di lingkungan keluarga, antar keluarga, banjar, dan desa adat. Etika dimaksud adalah setiap warga desa adat memiliki kedudukan dan peranan yang sama di depan aturan adat, sepanjang yang bersangkutan telah menjadi krama. Dalam persamaan hak dan kewajiban itu, kemudian untuk memberi dengan harapan menerima hal yang sama.
Senergi dua faktor ini menyebabkan masyarakat desa adat di Bali cendrung homogeny dalam referensi nilai, karakter, dan pilihan terhadap alternatif yang tersedia dalam hubungan menafsirkan serta memahami (interpretative and understanding) lingkungan sosial dan fisik. Kenyataan ini setidaknya terwakili dari didambakannya hubungan atas dasar prinsip Sagilik, Saguluk, Salulung Sabayanyaka.

Setiap krama merasa berkewajiban menjaga harmoni dengan sesamanya dengan cara sedapat mungkin menjaga agar mereka tidak dengan sengaja berusaha menonjol di atas krama lainnya. Tindakan konformisme dan egaliter senantiasa diterapkan itu bisa dilakukan kembali di masa mendatang dengan cara yang sama ekonomisnya. Pembiasaan akan membawa konsekuensi bahwa manusia tidak perlu lagi mendefinisikan kembali setiap situasi langkah demi langkah. Pembiasaan merupakan awal dari proses pelembagaan, yaitu terwujudnya tipifikasi yang timbal balik dari tindakan yang sudah dijadikan kebiasaan, yang membentuk lembaga, selalu merupakan miliki bersama.

Tindakan konformisme dan egaliter akhirnya dilembagakan, artinya segmen kegiatan setiap krama telah ditempatkan dibawah kendali sosial. Tipifikasi dalam interaksi ini akan terwujud karena kemampuan manusia dapat mengartikan serta meramalkan tindakan pihak lain, sehingga interaksi mereka secara keseluruhan dapat diramalkan. Ini adalah awal dari terbentuknya suatu dunia objektif, bentukan sosial yang dapat diteruskan kepada generasi sesudahnya.

Pengendapan intersubjektif para krama akan terjadi bilamana pengalaman yang 
lalu menjadi bagian dari suatu pengetahuan bersama. Pengendapan intersubjektif ini benar-benar bersifat sosial apabila ia telah diobjektivasi dalam suatu sistem tanda, yakni jika ada kemungkinan terulangnya objektivikasi pengalaman bersama itu. Apabila objektivikasi ini dapat berjalan dengan baik, maka oleh masyarakat akan dilegitimasi, yaitu suatu proses menghasilkan makna-makna baru yang berfungsi mengintegrasikan maknamakna yang telah diberikan arti pada proses pelembagaan. Fungsi hal itu adalah untuk membuat objektivasi "tingkat pertama" yang telah dilembagakan menjadi tersedia secara objekif dan masuk akal secara subjektif. Pengertian ini membawa pada tahapan penting dari proses legitimasi, yaitu (1) keseluruhan tatanan kelembagaan harus dapat dimengerti secara bersama-sama berdasarkan arti yang menyeluruh di balik motif-motif individu; keseluruhan kehidupan individu yang secara berturut-turut melalui berbagai tatanan dan kelembagaan harus diberi makna subjektif; (3) legitimasi mengandung teori-teori eksplisit, dalam arti dilegitimasi berdasarkan suatu perangkat pengetahuan yang berbedabeda. Legitimasi macam ini memberikan kerangka referensi yang komprehensif bagi setiap sektor perilaku yang telah melembaga. Karena kompleks, legitimasi itu sering kali dipercayakan kepada personil khusus melalui prosedur inisiasi yang telah diformalkan; dan (4) dalam wujud pengintegrasian berbagai bidang makna dalam tatanan kelembagaan sebagai totalitas simbolik yang disebut universum simbolik.

Ketiga, hubungan manusia dengan lingkungan atau Palemahan, beriakn dengan kejelasan batas wilayah desa adat, struktur Kahyangan dan Desa/banjar adat, serta pada menetap warga masyarakat desa adat sesuai konsepsi Tri Mandala. Orang Hindu diajarkan secara arif dan bijaksana menjaga keserasian hubungan dengan alam. Kebutuhan akan dunia sosial dan fisikal, memperkuat asumsi bahwa manusia tidak dapat hidup secara baik jikalau mereka terasing dari lingkungan sosialnya. Tidak hanya itu, manusia juga sedapat-dapatnya berusaha memelihara hubungan yang selaras dengan alam dan lingkungan di sekitarnya berdasarkan prinsip hubungan timbal balik. Dengan demikian, orang Hindu senantiasa berusaha memelihara hubunganhubungan bermakna itu dengan berbagai cara yang tepat dalam situasi dan kondisi tertentu. Orang Hindu dalam setiap kesempatan selalu berusaha memelihara baik hubungan-hubungan itu melalui wacana, perlambang, dan tanda sebagai bagian strategikebudayaannya agar tetap dapat hidup dan bertahan sebagai manusia (survival of the fittes).

Bertitik tolak dari ketiga dimensi itu (Parahyangan, Pawongan, dan Palemahan), dapat dinyatakan bahwa Tri Hita Karana sebagai konsepsi kebudayaan, dalam realitasnya dengan sistematis telah membentuk pengetahuan dasar (Basic Term) dikalangan warga desa adat. Pengetahuan itu, terutama berkaitan dengan kedudukan manusia diantara semesta alam sebagai makhluk yang malang; sementara pada horizon lain mereka harus dapat memelihara hubungan-hubungan bermakna diantara sesamanya berdasarkan prinsip timbal balik, dan hubungan manusia dengan alam. 
Pengetahuan dasar tentang keberadaan yang Supreme (Tri Kahyangan); keharmonisan tindakan sosial dan antar hubungan sosial sebagaimana terimplementasi dalam konsepsi SagilikSaguluk, Salulung Sabayantaka; dan keserasian dalam menjaga hubungan dengan alam fisik seperti dapat dipahami dalam konsepsi Tri Mandala, akhirnya membentuk 'mode' atau cara yang melembaga untuk hidup; dan terakhir membentuk pandangan tentang dunia (kosmologi) dan cara membentuk keteraturan itu.

\section{Forum Komunikasi Antar Desa Adat}

Forum komunikasi antar desa adat merupakan sarana bagi desa adat untuk memperlancar interaksi antara desa adat yang satu dengan desa adat lainnya. Hal itu upaya pemecahannya dapat diselesaikan oleh desa adat itu, dengan cara minta pertimbangan-pertimbangan dari desa adat lainnya. Melalui forum komunikasi antara desa adat itu, diharapkan berbagai program pembangunan dan pelaksanaan upacara-upacara yang menyangkut kepentingan umat, dapat dilaksanakan secara tertib di seluruh Bali. Dengan demikian, pembentukan forum komunikasi antar desa adat diharapkan masalah-masalah tantangan-tantangan dan hambatan-hambatan yang dihadapi oleh desa adat dalam pelaksanaan pembangunan diharapkan dapat diatasi. Kenyataan menunjukkan bahwa desa adat di Bali sangat bervariasi. Dilihat dari luas wilayahnya dan jumlah penduduknya sangat besar, tetapi ada pula wilayah desa adat yang sempit dengan jumlah penduduknya yang sedikit. Dilihat dari susunan kepengurusan, ada prajuru desa yang susunan kepengurusannya sederhana, yang terdiri dari seorang Kelihan adat dan dibantu oleh seorang kesinoman, tetapi ada pula susunan prajuru desa yang terdiri dari unsur ketua, sekretaris, bendahara dan beberapa pembantu. Dilihat dari mana jabatan kepengurusannya juga bervariasi, ada yang ditentukan batasnya, misalnya 5 tahun sekali diadakan pemilihan, tetapi ada beberapa pengurus desa yang masa jabatannya tidak ada batasnya. Variasi desa adat yang beraneka ragam tersebut mengandung berbagai jenis keunikan yang menarik. Kasus-kasus yang terjadi itu kadang-kadang bersifat spesifik. Sehingga upaya pemecahannya diperlukan pendekatan yang bersifat spesifik. Sehingga upaya pemecahannya diperlukan pendekatan yang bersifat spesifik pula sesuai dengan karakteristik desa adat tersebut.

Dengan adanya bantuan Pemerintah Daerah Tingkat I Bali diseluruh Bali, dapat dikatakan merupaan sarana komunikasi bagi para kelihan adat di Kantor Camat. Forum komunikasi setiap kelian ada di Kantor Camat, dapat diberdayakan untuk membahas berbagai masalah yang dihadapi oleh desa adat masing-masing.

Pembentukan berbagai jenis forum komunikasi antar desa adat, meliputi berbagai aspek kehidupan, seperti aspek ekonomi, politik, sosial budaya dan agama. Pada aspek ekonomi, terbentuklah LPD merupakan forum komunikasi bagi desa adat, untuk memecahkan berbagai kegiatan ekonomi.

Pada aspek politik atau pemerintahan, terbentuklah Majelis Pembina Lembaga Adat dan Badan Pelaksana Lembaga Adat, merupakan lembaga yang baik bagi desa adat untuk menyalurkan segala permasalahan yang dihadapinya. Oleh 
karena itu, pemanfaatan lembaga itu oleh desa adat, diharapkan akan dapat memecahkan permasalahan yang dihadapi oleh pihak desa adat.

Pada aspek sosial budaya, terbentuknya sanggar-sanggar budaya merupakan wadah bagi desa adat meningkatkan kreatifitas budaya. Kegiatan masyarakat desa adat pada berbagai kegiatan sosial, pada berbagai organisasi merupakan wadah komunikasi yang baik bagi desa adat.

Pada aspek agama terbentuknya berbagai organisasi pesantian, organisasi pemujaan bersama yang disertai dengan forum diskusi-diskusi merupakan wadah yang baik bagi desa adat untuk meningkatkan pemahaman dan penghayatan ajaran agama.

Dengan terbentuknya berbagai forum komunikasi yang meliputi berbagai aspek kehidupan masyarakat, diharapkan desa adat berdaya menghadapi sebagai tantangan dalam era globalisasi ini. Dengan demikian, ketahanan dan keberdayaan desa adat dapat dilihat dari fungsinya forum komunikasi antar desa adat yang dibentuk oleh desa adat masing-masing. Oleh karena itu, dapat dikatakan, bahwa semakin kompleks tantangan-tantangan yang dihadapi oleh desa adat, semakin perlu forum komunikasi antar desa adat diberdayakan.

\section{KESIMPULAN}

Beberapa simpulan yang dapat ditarik dari uraian di atas, adalah sebagai berikut : Desa adat yang memiliki otonomi asli, yang dapat mengatur rumah tangganya sendiri, dan dapat membuat ketentuan-ketentuan sendiri mempunyai peluang untuk tumbuh dan berkembang sesuai dengan perkembangan kehidupan masyarakat.
Desa adat dalam system pemerintahan Negara diakui keberadaannya, namun dengan adanya dualisme desa, yakni adanya desa adat dan desa dinas, dominasi desa dinas melemahkan posisi desa adat.

Tantangan-tantangan yang dihadapi desa adat semakin besar, namun dengan meningkatnya kebutuhan warga desa adat dan pesatnya dunia luar, sehingga forum komunikasi antara desa ada yang meliputi berbagai kehidupan perlu dibentuk oleh desa adat.

Berfungsinya Forum Komunikasi Antar Desa Adat yang dimaksudkan untuk mengatasi berbagai tantangan yang dihadapi desa adat, merupakan tolak ukur bagi ketahanan dan keberdayaan desa adat dalam era globalisasi.

\section{DAFTAR PUSTAKA}

Adeney, Bernard T. Etika Sosial Lintas Budaya, Yogyakarta : Kanisius.

Ardhana, Ketut. 2001.Bali Multibudaya.

Awuy, Tommy. 1995. Wacana Tragedi dan Dekontruksi Kebudayaan. Yogyakarta : Jentana Wacana.

--, Brigitte Berger and Handsfried Kaliner. 1992. Pikiran Kembara : Modernisasi dan Pikiran Manusia. Yogyakarta: Kanisius.

-. 1994. Kabar Angin dari Langit : Makna Teologi dalam Masyarakat Modern. Jakarta : LP3ES.

Budi, Hardiman, F. 1990. Kritik Ideologi: Pertautan Pengetahuan dan Kepentingan. Seri Pustaka Filsafat. Yogyakarta : Kanisius.

Dahrendorf, Ralf. 1986. Konflik dalam Masyarakat Industri : Sebuah Analisis Kritis. Jakarta : Rajawali.

Featherman, L. David. 1980. "Social Stratification and Mobility : Two Decades of Cumulative Social Science". Stanfor California : Paper 
the Author Condirected the 1980 Summer Institut at the Center for Advanced Study in the Behavioral Sceinces.

Fukuyama, Francis. 1999. Benturan Antarperadaban. Yogyakarta: Qalam.

--------. 2002. The Great Disruption. Yogyakarta : Qalam.

Galtung, John. 1991. "Suatu Teori Struktural Tentang Imperialisme" dalam Amir Effendi Serigar (ed) Arus Pemikiran Ekonomi Politik. Yogyakarta : Tiara Wacana.

Geertz, Clifford. 1986. "Perubahan Sosial dan Modernisasi Ekonomi di Dua Kota di Indonesia" dalam Agama, Etos Kerja dan Perkembangan Ekonomi. Jakarta : LP3ES.

---------.1992. Politik Kebudayaan. Yogyakarta: Kanisius.

Giddens Anthony and David Held. 1982 (Ali Mandan, Penyunting). Class, Power and Confict : Classical and Contemporary Debates. Jakarta : Rajawali.

Grusky, DB.1994.Social Stratification : Class, Race and Gender in Sociological Perspektive. Oxford : Westview Press.

Hafercamp, H and H.J. Smelser. 1992. Social Change and Modernity. Berkeley and Los Angeles, California : University of California Press.

Haryanto. 1991. Elite, Massa, dan Konflik. Yogyakarta: PAU Studi Sosial.

Heddy Shri Ahimsa Putra. 1988. Minawang : Hubungan PatronKlien di Sulawesi Selatan. Yogyakarta : Gajah Mada University Press.
Huntington, Samuel. P. Benturan Antar Peradaban dan Masa Depan Politik Dunia. Yogyakarta : Qalam.

Legg, Keith, R. 1983. Tuan, Hamba, dan Politisi. Jakarta: Sinar Harapan.

Lenski, Gerhard. 1966. Power and Privelege: A Theory of Social Stratification. New York : Mc. Graw Hill.

Ritzer, Goerge. 1980. Socilogy : A Multiple Paradigm Science. Boston : Allyn and Bacon.

Slotkin, J.S.1956. The Poyote Religion. Chicago : University of Chicago Press.

Wahid, Abdurrahman. 2001. Pergulatan Negara, Agama dan Kebudayaan, Depok : Desantara.

Wallace, Ruth and Alison, Worf. 1986. Contemporary Sociological Theory : Continuing The Classical Tradition. Englewood Cliffs, New Jersey : Prentise-Hall, Inc.

Wiyanta, AB.2002. Sosiologi Kebudayaan. Yogyakarta : Cindelaras Pustaka Rakyat Cerdas bekerjasama dengan Yayasan Adikarya Ikapi dan Ford Foundation.

Winardi, Jozef. 1991. Konflik dan Harmoni dalam Proses Pembangunan. Pidato Pengukuhan Guru Besar Tetap dalam Ilmu Administrasi Pembangunan FISIP UNPAD. Bandung.

Yudha Triguna. 1990. Munculnya Kelas Baru dan Dewangsanisasi: Transformasi Ekonomi dan Perubahan Sosial di Bali. Tesis S2. Yogyakarta : Isipol UGM.

-. 1997. Mobilitas Kelas, Konflik, dan Penafsiran Simbolisme Masyarakat Hindu di Bali (Disertasi). Bandung Universitas Pajajaran. 
-------. 2000. Mengenal Teori-Teori Pembangunan Denpasar : Vidya Dharma.

--------. 2000. Teori Tentang Simbol (Disertasi). Denpasar : Vidya Dharma.

2000. Kontribusi Hindu Terhadap Ilmu Pengetahuan dan Peradaban Denpasar : Vidya Dharma. 